\title{
FAKTOR PENGHAMBAT STUDI MAHASISWA YANG TIDAK LULUS TEPAT WAKTU DI JURUSAN PENDIDIKAN TEKNIK MESIN FT UNY
}

\author{
Widarto \\ Jurusan Pendidikan Teknik Mesin, Fakultas Teknik, Universitas Negeri Yogyakarta \\ widarto@uny.ac.id
}

\begin{abstract}
This paper aim to identify the students who cannot finish their course on time, addressing the inhibiting factor for their course completion, identify the students' efforts and struggle on their course completion, and to understand their expectations from the school administration to accommodate their course completion. The research used survey methods with questionnaire as the instrument were analyzed using quantitative-descriptive technique. The subjects of the research are the diploma and bachelor degree students of Mechanical Engineering Education Department. The results show that the inhibiting factors are the long commute to campus for supervisions, many students still taking coursework, students already have a job, passive supervisors, unconducive environment, and supervisions that were not intensively done. The students were still committed to complete their course supported by various efforts, namely intensive supervision, independent study or discussion, and finding a conducive environment to work on their final projects and theses. Students' expectations for the success of their course are the availability of final project and thesis in an earlier stage of their study, supervisor should be appointed based on their competency, increasing the allocated time of the final project schedule, the administration needs to renew the workshop's machinery and equipment, and cut off the unnecessary final project and Thesis administration steps.
\end{abstract}

Keywords: inhibiting factor, course completion, student expectation

\begin{abstract}
ABSTRAK
Tujuan penelitian ini yaitu mengidentifikasi mahasiswa yang tidak lulus tepat waktu, mengetahui faktor penghambat, mengetahui usaha-usaha yang dilakukan, dan harapan mahasiswa kepada pengelola Jurusan Pendidikan Teknik Mesin Fakultas Teknik Universitas Negeri Yogyakarta (Diknik Mesin FT UNY). Metode penelitian yaitu survey menggunakan angket dengan analisis deskriptif kuantitatif. Objek penelitian mahasiswa D3 Teknik Mesin dan S1 Pendidikan Teknik Mesin. Hasil penelitian menunjukan faktor kendala tidak lulus tepat waktu yaitu karena jarak yang jauh ke kampus untuk bimbingan, masih mengikuti kuliah, sudah bekerja, dosen kurang aktif, tempat tinggal kurang kondusif, dan bimbingan tidak intensif. Namun, mahasiswa berkomitmen untuk lulus tepat waktu dengan usaha, seperti bimbingan secara intensif, belajar mandiri atau diskusi, dan mencari lingkungan yang kondusif untuk mengerjakan Proyek Akhir dan Skripsi. Harapan mahasiswa yaitu mata kuliah Proyek Akhir dan Skripsi bisa diambil lebih awal, penentuan dosen pengampu mata kuliah relevan dengan kompetensinya, jadwal pelaksanaan Proyek Akhir perlu ditambah frekuensinya, peremajaan peralatan bengkel, dan permudah birokrasi.
\end{abstract}

Kata kunci: faktor penghambat studi, tidak lulus tepat waktu

\section{PENDAHULUAN}

Investasi di bidang sumber daya manusia (SDM) atau human investment, melalui pendidikan merupakan suatu proses yang panjang. Untuk menunjang keberhasilan pendidikan, perlu perencanaan yang matang, agar hasil pendidikan mencapai tujuan yang telah ditentukan. Pada dasarnya keberhasilan proses pendidikan merupakan kontribusi dari berbagai pihak yang terlibat proses di dalamnya, yaitu pendidik, peserta didik, kurikulum, sarana \& prasarana, waktu, biaya, dan subkomponen lainnya.

Pada jenjang pendidikan tinggi, yakni jenjang pendidikan baik D3, S1, S2, dan S3, jumlah peminatnya belakangan ini dirasakan terus meningkat. Jika diamati fakta 10 tahun yang lalu, seseorang akan melanjutkan 
pendidikan ke jenjang S1, S2 dan S3, setelah mereka bekerja dan mendapatkan penghasilan yang memadai. Kondisi tersebut sekarang sudah terbalik. Orang akan cenderung menempuh studi yang setinggi-tingginya dulu, baru bekerja.

Pendidikan pada jenjang S1 mestinya dapat ditempuh dalam waktu yang relatif singkat. Menurut peraturan akademik, jenjang S1 dapat ditempuh dalam waktu 4 tahun dan untuk jenjang D3 dapat ditempuh dalam waktu 3 tahun.

Kenyataannya, berdasarkan data di bagian akademik Jurusan Pendidikan Teknik Mesin FT UNY, masih banyak mahasiswa yang masa studinya lebih dari 4 tahun untuk S1 dan lebih dari 3 tahun untuk D3. Berangkat dari kondisi di atas, tujuan penelitian dapat dirumuskan untuk: (1) mengetahui faktor apa sajakah faktor penghambat penyelesaian studi mahasiswa Jurusan Diknik Mesin FT UNY; (2) bagaimana mahasiswa Jurusan Diknik Mesin FT UNY yang terhambat studinya masih berkomitmen kuat untuk menyelesaikan studi; (3) bagaimana usaha-usaha yang sudah dilakukan mahasiswa Jurusan Diknik Mesin FT UNY dalam rangka menyelesaikan studinya; (4) apakah harapan mahasiswa Jurusan Diknik Mesin FT UNY kepada pengelola dalam rangka penyelesaian studinya. Apabila faktor penghambat itu diketahui, segera ditindaklanjuti oleh pengelola untuk dapat menentukan langkah-langkah solusinya.

Konsep educated people (masyarakat terdidik) pada hakikatnya merupakan konsekwensi dari kebutuhan masyarakat dalam perubahan dan kebutuhan kehidupan. Artinya, pendidikan sebagai sebuah medium yang mampu mengantarkan peserta didik menjadi manusia terdidik yang berkompetensi menghadapi kehidupan dengan sebaiknya dalam kerangka mencapai tujuan pemanusiaan. Ada tiga konsep utama yang perlu dikaji sehubungan dengan pendidikan yang dianggap mampu menjadi alternatif pengembangan sumber daya dalam arti yang luas, yang dijelaskan sebagai berikut.

\section{Konsep Efisiensi Pendidikan}

Efisiensi pendidikan mengacu pada ukuran penggunaan daya yang digunakan oleh peserta didik. Efisiensi juga ditekankan pada perbandingan antara input (sumber daya) dengan output. H. Emerson (1853-1931) mengatakan efisiensi ialah keberhasilan optimal yang diraih padahal dengan bahan terbatas. Jadi efisiensi adalah usaha dalam meraih tujuan agar tercapai dengan maksimal meski dengan kemampuan terbatas. Sejalan dengan pernyataan tersebut, dalam Kamus Besar Ekonomi (2003), efisiensi adalah ketepatan cara (usaha, kerja) dalam menjalankan sesuatu (dengan tidak membuang waktu, tenaga, biaya), kedayagunaan, ketepatgunaan, kesangkilan serta kemampuan menjalankan tugas dengan baik dan tepat (dengan tidak membuang waktu, tenaga, biaya). Berdasarkan pengertian di atas, suatu kegiatan dikatakan efisien bila tujuan dapat dicapai secara optimal dengan penggunaan atau pemakaian sumber daya yang minimal. Efisiensi dengan demikian merupakan perbandingan antara input dengan output, tenaga dengan hasil, perbelanjaan dan masukan, serta biaya dengan kesenangan yang dihasilkan.

Dalam dunia pendidikan dapat diartikan sebagai kegairahan atau motivasi belajar yang tinggi, semangat kerja yang besar, kepercayaan berbagai pihak, dan pembiayaan, waktu, dan tenaga sekecil mungkin tetapi hasil yang didapatkan maksimal (Daulat, 2001: 31). Dengan demikian, efisiensi merupakan faktor yang sangat urgen dalam rangka manajemen peningkatan mutu pendidikan (Tjipto \& Kees, 1989: 40). Hal ini karena lembaga pendidikan secara umum dihadapkan pada masalah yang secara langsung berdampak terhadap kegiatan manajemen.

Di atas telah dikemukakan bahwa efisiensi merupakan perbandingan antara input dan output (Smith, 1991: 52). Dalam pendidikan, input adalah sumber daya yang digunakan untuk melaksanakan kegiatan pendidikan dan pengajaran dalam rangka 
mencapai tujuan yang telah dirumuskan. Sumber daya tersebut terkait dengan nilai, serta faktor manusia dan ekonomi. Nilai menggariskan tujuan serta isi pendidikan, faktor manusia merupakan pelaksana pendidikan, dan faktor ekonomi menyangkut biaya dan fasilitas penyelenggaraan. Secara operasional, masukan tersebut adalah peserta didik, guru, ruang kelas, buku teks, peralatan, kurikulum serta sarana pendidikan. Masukan ini bisa dinyatakan dalam bentuk biaya pendidikan per peserta didik setiap tahun. Sehingga untuk mengetahui tingkat efisiensi pengelolaan lembaga pendidikan, dapat dihitung dari banyaknya tahun yang dihabiskan peserta didik dalam siklus tertentu untuk menyelesaikan studinya. Efisiensi ini akan menurun jika ada peserta didik yang mengulang atau drop out (DO).

Selain dianalisis dari perbandingan komponen input dan output, efisiensi juga bisa ditinjau dari sisi proses pendidikan, di mana merupakan interaksi antara faktor manusiawi dan nonmanusiawi dalam rangka mencapai tujuan yang dirumuskan sesuai dengan rentang waktu yang telah ditentukan. Sehingga pendidikan dikatakan efisien jika proses atau kegiatan pengelolaan lembaga pendidikan dilakukan dalam waktu yang relatif singkat. Efisiensi dapat diklasifikasikan menjadi efisiensi internal dan eksternal. Efisiensi internal menunjuk kepada hubungan antara output pendidikan dan input (sumber daya) yang digunakan untuk memproses atau menghasilkan output pendidikan.

Ada tiga kategori teknik untuk memperbaiki efisiensi sistem pendidikan: efisiensi dapat diperbaiki dengan mengubah jumlah, kualitas, dan proporsi input atau dengan menggunakan input-input yang ada secara lebih intensif, tanpa mengubah secara mendasar kondisi dan teknologi yang ada atau fungsi produksi. Tahap berikutnya, efisiensi dapat ditingkatkan dengan memodifikasi rancangan dasar sistem secara substansial, meliputi pengenalan komponen-komponen dan teknologi baru yang berbeda, seperti pengajaran tim, televisi pendidikan, dan laboratorium bahasa. Pendekatan yang lebih radikal untuk memperbaiki efisiensi yang ada untuk merancang alternatif baru "sistem belajar mengajar" yang membedakan secara radikal dari yang konvensional.

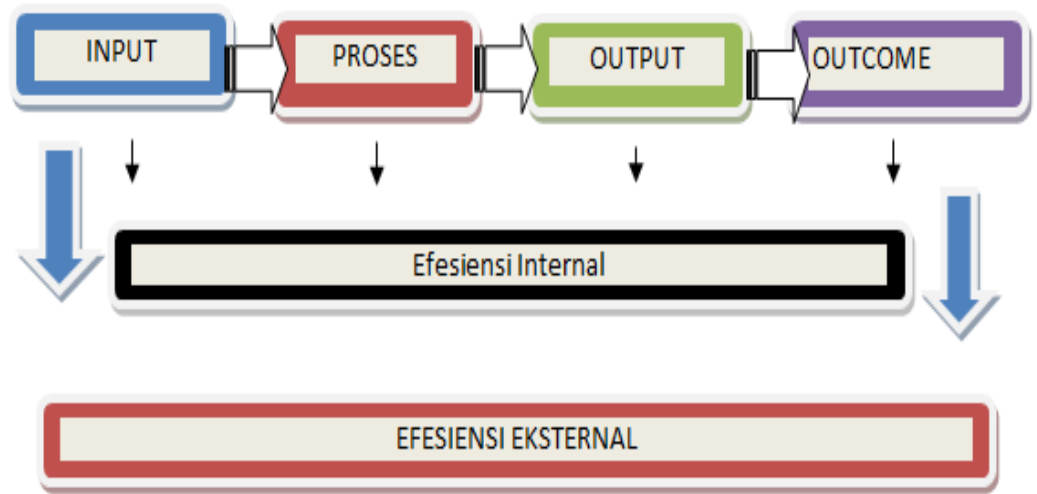

Gambar 1. Diagram konsep efisiensi pendidikan

Di atas telah dikemukakan bahwa efisiensi diklasifikasikan menjadi (1) efisiensi internal, dan (2) efisiensi eksternal. Dalam kajian sistem pendidikan, dengan diberlakukannya school based management diharapkan mampu meningkatkan mutu pendidikan melalui perbaikan serta peningkatan efisiensi internal pendidikan melalui inovasi manajemen serta pembelajaran yang menyertainya, seperti peningkatan peran dewan sekolah, penerapan Kurikulum Tingkat Satuan Pendidikan (KTSP), dll. Sementara itu 
efisiensi eksternal merujuk pada hubungan antara keuntungan kumulatif yang diperoleh dari sistem lebih dari satu periode tertentu dan input-input yang sesuai digunakan dalam menghasilkan keuntungan.

Dalam dunia pendidikan, upaya dalam rangka meningkatkan efisiensi pendidikan dalam konteks peningkatan mutu, paling tidak dapat ditentukan oleh dua hal, yakni: manajemen pendidikan yang profesional dan partisipasi dalam pengelolaan pendidikan yang meluas. Dalam hal ini, analisis terhadap efisiensi pendidikan juga dapat dilakukan dengan dua pendekatan, yaitu pendekatan dengan tidak memperhatikan secara terinci unsur-unsur biaya yang digunakan dalam proses pendidikan (agregate approach), serta pendekatan yang memperhitungkan kontribusi biaya secara terinci dalam proses pendidikan untuk menghasilkan keluaran (ingredient approach). Kedua pendekatan nampak berbeda dalam memperhitungkan biaya dalam proses pendidikan, yang satu menggunakan total biaya dalam menilai kontribusi biaya terhadap pendidikan, sedangkan yang satu memperhitungkan kontribusi per unsur. Namun demikian, tujuan yang ingin dicapai kedua pendekatan tersebut sama, yaitu mengidentifikasi dampak mapun ekses penggunaan biaya.

Dari penjelasan di atas nampak jelas bahwa perbedaan karaktersitik situasi dan input yang terlibat mempunyai implikasi pada biaya pendidikan yang diperlukan. Karena itu keputusan tentang efisiensi haruslah kontekstual dan proporsional. Keputusan kontekstual dan proporsional ini sangat membutuhkan ketersediaan informasi tentang karakteristik situasi dan input yang terlibat dalam proses pendidikan dalam jumlah dan mutu yang memadai.

Dengan demikian, dalam menganalisis efektifitas mutu pendidikan sebagaimana juga dalam efektifitas pendidikannya harus diperhatikan aspek input dan proses pendidikan tersebut. Berkenaan dengan hal tersebut, maka sistem pendataan yang akurat, tepat guna, dan waktu perlu dikonstruksi secara mendasar melalui peningkatan kemampuan staf, arus data yang melekat dalam proses manajemen, serta sarana prasarana pendukung.

Dalam konteks peningkatan mutu pendidikan melalui efisiensi pengelolaan pendidikan, analisis serta pengkajian data dan informasi perlu dilakukan secara simultan, terus-menerus, dan mendalam agar setiap unit kerja dalam lembaga pendidikan dapat melaksanakan manajemen secara efisien.

\section{Konsep Efektivitas Pendidikan}

Konsep efektifitas merupakan sebuah fenomena yang mengandung banyak segi, sehingga sedikit sekali orang yang dapat memaksimalkan keefektifannya. Atau dapat dikatakan bahwa efektivitas masih merupakan sebuah konsepsi yang bersifat exclusive (sulit diraih) yang harus didefinisikan secara jelas. Sehingga efektivitas lembaga pendidikan memiliki arti yang berbeda bagi setiap orang, bergantung pada kerangka acuan yang dipakai. Ada yang mengatakan, keefektifan merupakan derajat di mana sebuah organisasi mencapai tujuannya. Sedangkan di sisi lain ada juga yang memaknai, keefektifan merupakan kesesuaian antara hasil yang dicapai oleh organisasi dengan tujuan yang telah dirumuskan. Kemudian Scheerens $(2000 ; 32)$ mengemukakan bahwa efektivitas sebagai konsep kausal secara esensial, di mana hubungan maksud-hingga-tujuan (means-toend relationship) serupa dengan hubungan sebab-akibat (cause-effect relationship). Terdapat tiga komponen utama yang harus diperhatikan dalam studi tentang efektivitas organisasi pendidikan, yaitu: (1) cakupan pengaruh; (2) kesempatan aksi yang digunakan untuk mencapai pengaruh tertentu (ditandai sebagai mode pendidikan); dan (3) fungsifungsi dan mekanisme yang mendasari yang menjelaskan mengapa tindakan tertentu mendorong ke arah pencapain-pengaruh.

Dari definisi tersebut dapat dipahami bahwa efektifitas lembaga pendidikan 
merupakan kemampuan lembaga itu untuk merealisasikan berbagai tujuan dan kemampuannya untuk beradaptasi dengan lingkungan dan mampu bertahan agar tetap eksis/hidup. Sehingga lembaga pendidikan dikatakan efektif jika dia mampu menciptakan suasana belajar di mana para peserta didik tidak hanya melaksanakan tugas yang telah dibebankan kepadanya, tetapi juga membuat suasana agar peserta didik lebih bertanggung jawab, bertindak secara kreatif demi peningkatan efisiensi dalam mencapai tujuan.

Konsep efektivitas pendidikan mengacu pada kinerja unit organisasi lembaga pendidikan. Oleh sebab itu maksud dari efektivitas sesungguhnya pencapaian tujuan, maka asumsi kriteria yang digunakan harus mencerminkan sasaran akhir dari organisasi itu sendiri. Efektifitas pendidikan dalam setiap tahapannya berproses pada das sollen dan dessein dengan indikator-indikator sebagai berikut:

1. Indikator input, meliputi karakteristik guru, fasilitas, perlengkapan dan materi pendidikan serta kapasitas manajemen.

2. Indikator process, meliputi perilaku administratif, alokasi waktu guru, dan alokasi waktu peserta didik.

3. Indikator output, berupa hasil-hasil dalam bentuk perolehan peserta didik meliputi hasil prestasi belajar, sikap, keadilan dan persamaan.

4. Indikator outcome, meliputi jumlah lulusan ke tingkat pendidikan berikutnya, prestasi belajar di sekolah yang lebih tinggi, pekerjaan, serta pendapatan.

Sebagaimana dijelaskan di atas bahwa efektifitas merupakan satu dimensi tujuan manajemen yang berfokus pada hasil, sasaran, dan target yang diharapkan. Lembaga pendidikan yang efektif adalah lembaga pendidikan yang menetapkan keberhasilan pada input, process, output, dan outcome yang ditandai dengan berkualitasnya indikatorindikator tersebut. Sehingga dengan demikian, efektifitas lembaga pendidikan bukan sekedar pencapaian sasaran dan terpenuhinya berbagai kebutuhan untuk mencapai sasaran, tetapi berkaitan erat dengan syaratnya indikator tersebut dengan mutu, atau dengan kata lain ditetapkannya pengembangan mutu lembaga pendidikan. Barometer efektifitas pendidikan dapat dilihat dari kualitas program, ketepatan penyusunan, kepuasan, keluwesan, dan adaptasi, semangat kerja, motivasi, ketercapaian tujuan, ketepatan waktu, serta ketepatan pendayagunaan sarana \& prasarana, dan sumber belajar dalam meningkatkan mutu lembaga pendidikan.

Jadi, jelas bahwa kajian tentang efektifitas pendidikan harus dilihat secara sistemik mulai dari input sampai dengan outcome, dengan indikator yang tidak hanya bersifat kuantitatif, tetapi juga bersifat kualitatif. Sudah lama kita mendambakan sebuah pendidikan yang berkualitas, sehingga tuntutan terhadap kualitas sangat semarak dan perwujudannya sangat urgen karena mutu sudah menjadi a very critical competitive variable dalam persaingan internasional.

\section{Konsep Produktivitas Pendidikan}

Konsep produktivitas merupakan perbandingan terbaik antara hasil yang diperoleh (output) dengan jumlah sumber yang dipergunakan (input). Produktivitas dapat dinyatakan dengan kuantitas maupun kualitas. Kuantitas output merupakan jumlah lulusan, sedangkan input merupakan jumlah tenaga kerja sekolah, dan sumber daya lainnya. Sedangkan produktivitas dalam ukuran kualitas tidak dapat diukur dengan uang, Ia digambarkan dari ketetapan penggunaan metode dan alat yang tersedia sehingga volume dan beban kerja dapat diselesaikan sesuai dengan waktu yang tersedia serta mendapatkan respon positif bahkan pujian dari orang lain atas hasil kerjanya. R.Saint-Paul dalam Asian Producticity Congress (1980), mengemukakan secara sederhana produktivitas yaitu hubungan antara kualitas yang dihasilkan dengan jumlah kerja yang dilakukan untuk mencapainya. Ada pula yang menekankan produktivitas pada sisi pemberian perhatian dan kepuasan kepada 
pelanggan, sehingga semakin banyak dan semakin memuaskan pelayanan yang diberikan sebuah lembaga terhadap pelanggan, maka semakin produktif lembaga tersebut.

Konsep produktivitas dalam dunia pendidikan berkaitan erat dengan keseluruhan proses penataan dan penggunaan sumber daya untuk mencapai tujuan pendidikan secara efektif dan efisien. Dalam konteks produktivitas pendidikan, sumber-sumber pendidikan dipadukan dengan cara-cara yang berbeda. Perpaduan tersebut sama halnya dengan upaya memproduksi pakaian yang menggunakan teknik-teknik yang berbeda dalam memadukan buruh, modal, dan pengetahuan. Untuk mengusai teknik-teknik tersebut diperlukan proses belajar. Seiring dengan bertambahnya waktu, semakin besar pula modal untuk pendidikan. Sekolah pun semakin berkembang seiring dengan besarnya tuntutan pendidikan yang harus dikembangkan. Perubahan dalam intensitas tenaga kependidikan pun kemudian harus dilakukan dan disesuaikan dengan kebutuhan sehingga perlu diaplikasikan model ketrampilan mengajar yang bervariasi.

Secara sederhana produktivitas pendidikan dapat diukur dengan melihat indeks pengeluaran riil pendidikan seperti dalam National Income Blue Book, dengan cara menjumlahkan pengeluaran dari banyaknya peserta didik yang dididik. Namun cara ini merupakan pengukuran cara kasar terhadap produk riil kependidikan. Cara ini pun tidak menceritakan sama sekali tentang kualitas lulusan lembaga pendidikan, juga derajat efisiensi berbagai sumber yang digunakan. Sehingga pengukuran output pendidikan dengan cara yang rasional penting untuk dipertimbangkan, namun juga perlu disadari bahwa pengukuran ini tidak dapat memberi indikasi langsung mengenai kuantitas pengajaran yang diterima setiap peserta didik. Produktifitas pendidikan dapat ditinjau dari 3 dimensi sebagai berikut :

1. Meninjau produktivitas sekolah dari segi keluaran administratif, yaitu seberapa besar dan seberapa baik layanan yang dapat diberikan dalam proses pendidikan, baik oleh guru kepala sekolah maupun pihak lain yang berkepentingan.

2. Meninjau produktivitas dari segi keluaran perubahan prilaku, dengan melihat nilainilai yang diperoleh peserta didik sebagai suatu gambaran prestasi akademik yang telah dicapainya dalam periode belajar tertentu di sekolah.

3. Melihat produktivitas sekolah dari keluaran ekonomis yang berkaitan dengan pembiayaan layanan pendidikan di sekolah. Hal ini mencakup "harga" layanan yang diberikan (pengorbanan atau cost) dan perolehan yang ditimbulkan oleh layanan itu atau disebut peningkatan nilai baik.

Jadi, jelas bahwa pengukuran produktivitas pendidikan erat kaitannya dengan pertumbuhan ekonomi, yang sangat bergantung pada akurasi kerangka yang digunakan dalam analisis dan kualitas data. Dalam konteks ini agaknya tidak perlu diperdebatkan bagaimana pengukuran pendidikan dalam pertumbuhan ekonomi, sebab umumnya riset mengenai ini membuktikan bahwa peranan pendidikan tetap substansial dalam pertumbuhan ekonomi. Sehubungan dengan hal tersebut, untuk mengetahui produktivitas pendidikan dalam konteks peningkatan mutu pendidikan, antara lain dapat dilakukan dengan: analisis efektivitas biaya, analisis biaya minimal, dan analisis manfaat sebagai usaha peningkatan mutu dan pemerataan pendidikan.

Untuk memperbaiki mutu proses pencerdasan bangsa yang berkelanjutan, pelaksanaan pendidikan jalur sekolah melalui pendidikan dasar, pendidikan menengah dan pendidikan tinggi serta pendidikan jalur luar sekolah, maka perlu disinergikan aktivitasnya. Lembaga pendidikan harus menempatkan dirinya sebagai pusat keunggulan (center of excellence) dalam pemberdayaan sumber daya manusia (SDM).

Keberadaan lulusan lembaga pendidikan merupakan SDM yang menjadi subjek dan objek pembangunan yang perlu terus 
ditingkatkan kualitasnya. Semua jalur pendidikan dalam fungsi, proses, dan aktivitasnya, harus bermuara pada pencapaian tujuan pendidikan yang telah ditetapkan.

\section{METODE}

Penelitian ini menggunakan pendekatan survey. Sumber data penelitian adalah mahasiswa Jurusan Diknik Mesin FT UNY baik Program Studi D3 Teknik Mesin maupun S1 Pendidikan Teknik Mesin yang belum menyelesaikan studinya sampai batas waktu yang ditentukan sesuai Peraturan Akademik. Teknik pengumpulan data menggunakan instrument/angket yang berisi pertanyaan dan pernyataan. Ada beberapa item yang sifatnya pertanyaan tertutup dan sebagian berupa pertanyaan terbuka.Data yang diperoleh dari angket dianalisis deskriptif kuantitatif.

\section{HASIL DAN PEMBAHASAN}

Mahasiswa D3 Teknik Mesin

Dalam penelitian hambatan studi khususnya mahasiswa D3 Teknik Mesin, jumlah mahasiswa yang terjaring atau sebagai objek penelitian adalah 35 orang berasal dari angkatan 2010 dengan rentang usia 21-22 tahun. Adapun setatus Proyek Akhir saat ini sebagai berikut:

Tabel 1. Status mahasiswa D3

\begin{tabular}{|c|c|c|}
\hline Posisi PA & $\begin{array}{l}26 \\
\text { orang } \\
9 \text { orang }\end{array}$ & $\begin{array}{l}\text { Penyusuna } \\
\text { n laporan } \\
\text { Sudah } \\
\text { daftar ujian }\end{array}$ \\
\hline Bimbingan PA & $\begin{array}{l}17 \\
\text { orang } \\
18 \\
\text { orang }\end{array}$ & $\begin{array}{l}\text { Rutin } \\
\text { Tidak rutin }\end{array}$ \\
\hline Frekwensi bimbingan & $\begin{array}{l}13 \\
\text { orang } \\
9 \text { orang } \\
13 \\
\text { orang }\end{array}$ & $\begin{array}{l}1-2 \text { kali } \\
\text { per minggu } \\
2 \text { kali } \\
\text { sebulan } \\
\text { tidak } \\
\text { menentu }\end{array}$ \\
\hline $\begin{array}{l}\text { Bimbingan yang } \\
\text { diharapkan }\end{array}$ & $\begin{array}{l}35 \\
\text { orang }\end{array}$ & Individu \\
\hline
\end{tabular}

Kesulitan mahasiswa dalam menyelesaikan studi telah tersusun dalam tabel indeks kesulitan studi mahasiswa. Adapun tabel ranking penghambat studi adalah sebagai berikut:

Tabel 2. Ranking kesulitan mahasiswa D3 Teknik Mesin saat menyusun Proyek Akhir

\begin{tabular}{|c|c|c|c|}
\hline $\begin{array}{c}\text { No. } \\
\text { Ranking }\end{array}$ & $\begin{array}{c}\text { Indeks } \\
\text { kesulitan }\end{array}$ & Uraian & Kategori \\
\hline 1 & 5.8 & $\begin{array}{l}\text { Mendapatkan } \\
\text { kelompok } \\
\text { yang cocok }\end{array}$ & Tinggi \\
\hline 2 & 5.4 & $\begin{array}{l}\text { Menemui } \\
\text { pembimbing }\end{array}$ & Tinggi \\
\hline 3 & 4.8 & $\begin{array}{l}\text { Mendapatkan } \\
\text { teman } \\
\text { diskusi }\end{array}$ & Sedang \\
\hline 4 & 4.4 & $\begin{array}{l}\text { Membangun } \\
\text { kekompakan } \\
\text { kelompok }\end{array}$ & Sedang \\
\hline 5 & 4.2 & $\begin{array}{l}\text { Menentukan } \\
\text { judul }\end{array}$ & Sedang \\
\hline 6 & 4.2 & $\begin{array}{l}\text { Proses } \\
\text { pembuatan }\end{array}$ & Sedang \\
\hline 7 & 4 & $\begin{array}{l}\text { Menulis } \\
\text { proposal }\end{array}$ & Sedang \\
\hline 8 & 4 & $\begin{array}{l}\text { Menemukan } \\
\text { masalah }\end{array}$ & Sedang \\
\hline 9 & 3.8 & $\begin{array}{l}\text { Menulis } \\
\text { laporan }\end{array}$ & Rendah \\
\hline 10 & 3 & $\begin{array}{l}\text { Mendapatkan } \\
\text { buku/jurnal } \\
\text { referensi } \\
\text { yang relevan }\end{array}$ & Rendah \\
\hline
\end{tabular}

Selanjutnya, berikut ditampilkan beberapa harapan mahasiswa untuk mempercepat studi atau pada saat menyusun Poyek Akhir diantaranya: (1) pelaksanaan Proyek Akhir sebaiknya dilakukan di awal semester 5; (2) pemberian informasi kepada mahasiswa lebih cepat; (3) peralatan penunjang kegiatan belajar perlu diperbanyak; (4) peralatan - peralatan bengkel diperbanyak; (5) penjadwalan kerja bengkel untuk Proyek Akhir agar lebih efektif; (6) ceramah tamahan \& pelayanan perlu diperbaiki; (7) pelayanan di diknik kurang baik, sehingga perlu diperbaiki; (8) mesin - mesin produksi banyak yang troble \& kurang perawatan, perlu diperbaiki; dan (9) fasilitas perlu diperbaiki \& perbaharui. 


\section{Mahasiswa S1 Pendidikan Teknik Mesin}

Data mahasiswa S1 yang belum lulus dan terjaring sebagai responden penelitian dari angkatan 2007-2009 berjumlah 21 orang dengan rentang umur 22-25 tahun. Jumlah mahasiswa yang tidak sedikit ini berdampak pada penilaian akreditasi institusi Jurusan Diknik Mesin FT UNY dan kultur belajar yang semakin melemah dikalangan mahasiswa, khususnya pada angkatan selanjutnya. Kondisi ini dipengaruhi beberapa data pendukung yang menyebabkan mahasiswa terlambat lulus studi tepat waktu, di antaranya:

Tabel 3. Status Mahasiswa S1

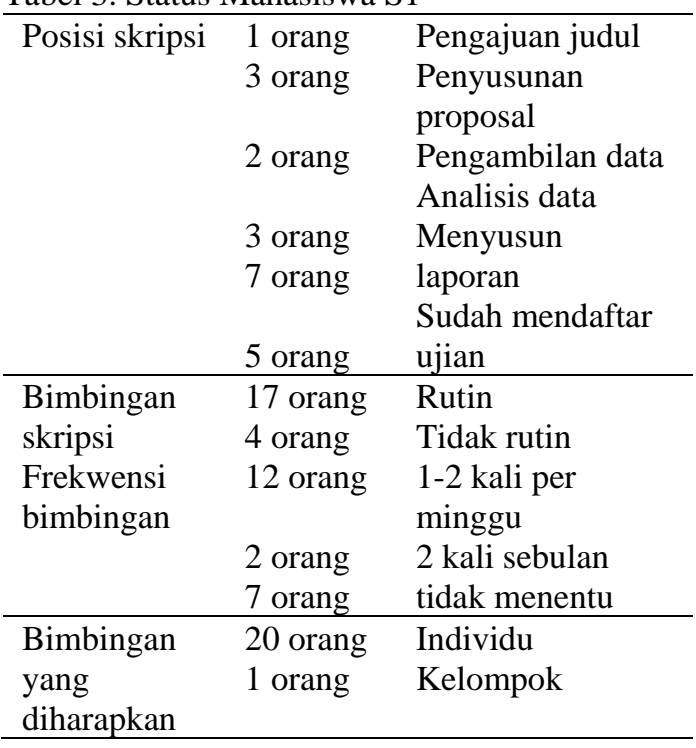

Tabel 6. Ranking kesulitan mahasiswa S1 saat menyusun skripsi

\begin{tabular}{|c|c|c|}
\hline $\begin{array}{c}\text { No. } \\
\text { Ranking }\end{array}$ & $\begin{array}{l}\text { Indeks } \\
\text { kesulitan }\end{array}$ & Uraian \\
\hline 1 & 6.38 & Menentukan judul \\
\hline 2 & 6.24 & Menemukan masalah \\
\hline 3 & 6.05 & Proses analisis data \\
\hline 4 & 6.05 & Menulis laporan penelitian \\
\hline 5 & 5.86 & Menulis proposal \\
\hline 6 & 5.81 & $\begin{array}{l}\text { Mendapatkan teman } \\
\text { diskusi }\end{array}$ \\
\hline 7 & 5.67 & $\begin{array}{l}\text { Pengambilan data } \\
\text { penelitian }\end{array}$ \\
\hline 8 & 5.52 & $\begin{array}{l}\text { Mendapatkan ijin dari } \\
\text { lokasi penelitian }\end{array}$ \\
\hline 9 & 4.38 & Menemui pembimbing \\
\hline 10 & 4.00 & $\begin{array}{l}\text { Mendapatkan buku/jurnal } \\
\text { sebagai referensi yang } \\
\text { relevan }\end{array}$ \\
\hline
\end{tabular}

Kesulitan yang mencolok pada penyusunan laporan skripsi. Pada prinsipnya, penulisan ini terkait dengan teknis menyajikan data yang sudah dimiliki kemudian disusun dengan baik menjadi sebuah laporan skripsi. Namun, karena mahasiswa kurang terbiasa tulis- menulis, maka ada yang cepat menyusun laporan skripsi dan tidak sedikit mahasiswa yang kesulitan menyusun laporan skripsi. Oleh karena itu, perlu dianalisis secara mendalam tingkat kesulitan mahasiswa S1 dalam menyelesaikan studinya. Harapan mahasiswa terangkum sebagai berikut: (1) mempermudah mahasiswa dengan memberi rekomendasi bahan skripsi; (2) sebaiknya setiap dosen membuat jadwal bimbingan rutin; (3) persamaan pesepsi sudut pandang skripsi sesama dosen; (4) pengambilan data skripsi seharusnya pd saat KKN/PPL; (5) lakukan bimbingan skripsi seperti perkuliahan biasa dengan presensi; dan (6) pelayanan mohon lebih ramah

\section{Kesulitan mahasiswa D3 Teknik Mesin dalam menyelesaikan studinya}

Mahasiswa D3 TM yang mengalami kesulitan menyelesaikan studi ada dua faktor utama penyebabnya. Pertama, hal yang mempunyai indeks kesulitan tertinggi dan menjadi penghambat studi mahasiswa adalah mendapatkan kelompok Proyek Akhir yang cocok. Proyek Akhir di sini merupakan syarat wajib yang harus ditempuh mahasiswa Diploma 3 dengan membuat produk berupa mesin tepat guna. Dalam pembuatannya dibentuk kelompok yang paling tidak terdiri dari 3 mahasiswa atau lebih dan diharapkan setiap konsentrasi mahasiswa masuk dalam kelompok yaitu Perancangan, Fabrikasi, dan Pemesinan. Pada tahapan teknis pembuatan Proyek Akhir, kekompakan anggota kelompok sangat diperlukan dalam menyelesaikan pekerjaan, dan kesadaran untuk saling mendukung dari anggota menjadi poin paling penting.

Dalam membentuk kelompok, sebenarnya pengurus jurusan sudah 
membebaskan pada setiap mahasiswa untuk memilih rekan dan membentuk sebuah kelompok Proyek Akhir. Tetapi mungkin karena dalam satu kelompok Proyek Akhir paling tidak ada mahasiswa yang berasal dari option Perancangan, Fabrikasi, dan Pemesinan sehingga pemilihan anggota juga berdasarkan hal tersebut.

Membahas kecocokan anggota, sebenarnya dengan tuntutan yang ada yaitu paling tidak terdapat option Perancangan, Fabrikasi dan Pemesinan ini tergantung individu masing-masing. Setiap individu harus benar-benar siap menyatu dan bisa bekerja sama untuk menyelesaikan Proyek Akhir ini. Seperti yang sudah dilaksanakan, dalam penyelesaian Proyek Akhir mahasiswa dari setiap option mempunyai peran yang sama pentingnya dalam proses pembuatan Proyek Akhir.

Mahasiswa yang berasal dari option Perancangan berperan merancang produk, menganalisis produk sampai pada gambar kerja. Mahasiswa dari option Pemesinan mempunyai tugas mengerjakan bagian yang berhubungan dengan pemesinan. Sementara mahaiswa yang dari option Fabrikasi mempunyai tugas yang berhubungan dengan pengelasan. Dalam pembuatan Proyek Akhir ini, pembelajaran yang dapat diambil adalah bukan semata-mata hard skills yang berkaitan dengan keahlian masing-masing option yang ada tetapi juga soft skills seperti kerjasama, tanggungjawab dan juga saling menghargai antar anggota kelompok. Mahasiswa harus siap menerima kelompok mereka dan benar-benar berkerja sama dalam menyelesaikan Proyek Akhir. Hal ini juga bisa diambil sebagai pembelajaran bagi mahasiswa karena dalam dunia kerja, tidak ada pilih-pilih, mereka harus siap bekerja di tempat kerja yang sudah menerima mereka.

Kasus yang biasa terjadi adalah terkadang anggota yang sudah selesai ujian, menghilang begitu saja dan anggota yang lain yang mungkin masih membutuhkan mengalami kesulitan. Sehingga jurusan tentunya harus mengupayakan komunikasi antar anggota tetap terjaga sampai semua anggota sudah lulus Proyek Akhir.

Penghambat kedua dalam menyelesaikan studi mahasiswa D3 adalah menemui pembimbing. Menemui pembimbing di sini terkait komunikasi yang baik antara mahasiswa yang dibimbing dan pembimbing. Pembimbing ataupun dosen tentunya juga punya agenda/pekerjaan yang lain seperti mengajar, penelitian, pengabdian pada masyarakat ataupun hal-hal lainnya. Untuk mengatasi keefektifan bimbingan sebaiknya pembimbing dan mahasiswa saling mengkomunikasikan waktu bimbingan ataupun pembimbing bisa me-share jadwal harian mereka selama di kampus yang bisa diakses secara mudah oleh mahasiswa bimbinganya seperti ditempel di pintu ruang kantor, dll. Sehingga dengan saling berkomunikasi secara langsung ataupun dengan mengetahui jadwal pembimbing, mahasiswa dapat lebih efektif menentukan waktu bimbingan dan juga mengurangi penggunakan waktu untuk menunggu dosen.

Mengenai harapan mahasiswa, secara umum harapan terbanyak untuk mempercepat studi adalah pelaksanakan Proyek Akhir di awal semester 5. Hal ini karena pada saat ini Proyek Akhir dimulai pada akhir semester 5 menuju awal semester 6. Pada hal jika melihat jadwal reguler mahasiswa Diploma pada semester 5 bebas teori dan banyak waktu luang sehingga bisa dioptimalkan untuk membuat Proyek Akhir. Menentukan pelaksanakan di awal semester 5 tentunya harus diikuti dengan konsekuensi pembuatan proposal perancangan dan gambar kerja sudah selesai di akhir semester 4. Tugas ini secara khusus dikerjakan oleh perancangan sebagai pimpinan proyek. Di semester 4 mahasiswa mahasiswa harus mengambil mata kuliah Perancangan Elemen Mesin dapat bersinergi dengan Proyek Akhir, sehingga diharapkan output setelah selesai mengikuti kuliah adalah Proposal Proyek Akhir lengkap dengan gambar kerja. Sehingga 
realisasi pembuatan dapat dilakukan di awal semester 5 .

\section{Kesulitan mahasiswa S1 Pendidikan Teknik Mesin dalam menyelesaikan studinya}

Ada 10 kesulitan berdasarkan angket yang sudah diberikan kepada 21 mahasiswa sebagai responden penelitian. Kondisi ini menjadikan mahasiswa terhambat lulus tepat waktu. Hasil angket ada 3 faktor utama yang menyebabkan kesulitan mahasiswa menyelesaikan studinya. Kesulitan pertama terjadi pada menentukan judul skripsi. Judul skripsi sebagai modal awal mahasiswa untuk dapat mengerjakan skripsi. Ada beberapa hal yang perlu diperhatikan dalam membuat judul skripsi, yaitu:

1. Judul yang dibuat sudah memuat permasalahan dan solusinya.

2. Memberi rasa penasaran atau rasa ingin tahu bagi pembaca.

3. Kalimat judul tidak mengandung dua makna judul penelitian yang berbeda.

4. Kalimat harus jelas, singkat, dan menarik bagi pembaca.

Kedua, kesulitan mahasiswa S1 saat menyusun skripsi adalah menemukan masalah. Mahasiswa yang tidak paham penelitian akan berat untuk mencari masalah penelitian. Bila dicermati, masalah penelitian sebenarnya ada di sekitar kita (masyarakat). Penelitian pendidikan misalnya tentang penerapan metode pembelajaran, pembuatan media pembelajaran, kebijakan pendidikan, dan sebagainya. Namun, pada kenyataan mahasiswa kesulitan untuk memunculkan berbagai permasalahan penelitian. Bahkan, ada yang berpendapat bahwa mencari masalah penelitian sebenarnya itu sudah menjadi masalah bagi tiap individu mahasiswa. Kondisi ini disebabkan beberapa faktor, seperti kurang pekanya mahasiswa dalam menanggapi masalah pendidikan, kurang banyak membaca buku khususnya tentang pendidikan, dan mahasiswa tidak suka melakukan penelitian.

Ketiga, kesulitan mahasiswa terletak pada menganalisis data penelitian. Data penelitian yang sudah didapatkan sulit untuk diartikan sesuai dengan rencana. Awal menggunakan rencana $\mathrm{A}$, tetapi saat menganalisis tidak sesuai dengan rencana $\mathrm{A}$ atau data yang didapatkan tidak sesuai rencana. Kondisi ini membuat mahasiswa merasa kebingungan menganalisis data. Kejadian ini tidak akan bisa menghasilkan solusi yang bermakna dari penelitian yang dilakukan. Hal ini disebabkan beberapa faktor, di antaranya:

1. Saat mengambil data tidak disesuaikan dengan rencana penelitian.

2. Kurangnya pengetahuan mahasiswa bila menemukan data yang tidak sesuai dengan rencana.

3. Kurangnya membaca buku atau jurnal penelitian sebagai referensi untuk menganalisis data.

4. Tingkat kemampuan menganalisis suatu data menjadi hasil solusi penelitian yang masih kurang bagi mahasiswa.

Indeks kesulitan mahasiswa saat menyusun skripsi menjadi cerminan institusi pendidikan (universitas) agar mampu menghasilkan lulusan yang berkualitas. Institusi pendidikan Universitas Negeri Yogyakarta (UNY) khususnya Jurusan Pendidikan Teknik Mesin bisa memberikan pelayanan bagi mahasiswa dalam menyelesaikan studinya. Perencanaan sosialisasi atau pemberian mata kuliah skripsi dilakukan sejak semester 5 atau 6 , sehingga mahasiswa punya gambaran tema apa yang akan dijadikan penelitian. Pelayanan yang tidak kalah pentingnya pemilihan dosen pembimbing skripsi. Pemilihan dosen pembimbing harus disesuaikan dengan ide penelitian mahasiswa. Dosen yang berkompeten di bidang tersebut akan mempermudahkan mahasiswa dalam menghasilkan penelitian yang berkualitas. Selain itu, dosen juga aktif untuk membimbing mahasiswa dengan cara mudah ditemui dan banyak waktu bagi mahasiswa dalam membimbing skripsi. Hasil bimbingan yang diharapkan mahasiswa bisa memberikan solusi dan pemberian beberapa referensi untuk 
mempermudah mahasiswa dalam menyelesaikan skripsi.

Bimbingan yang aktif dilakukan oleh dosen harus diimbangi oleh ketersediaan sarana buku referensi bagi mahasiswa. Penelitian yang dibuat perlu didukung dengan berbagai sumber referensi agar hasil penelitian semakin kuat dan solusi yang dijabarkan mampu memecahkan permasalahannya. Oleh karena itu, ketersediaan buku di perpustakaan baik dalam bentuk hardcopy (buku cetakan) maupun softcopy (e-book) perlu ditingkatkan pelayanan untuk mahasiswa. Berbagai tahapan penelitian yang sudah dilalui sampai menghasilkan laporan penelitian perlu diperhatikan juga masalah administrasi untuk mengurus ujian skripsi, yudisium, dan wisuda. Ketiga bagian ini saling berkaitan dan diperlukan pelayanan yang sesuai dengan aturan tetapi tidak mempersulit mahasiswa untuk mengurusnya. Pelayanan ini akan membantu secara psikologis bagi mahasiswa agar tetap terjaga semangat untuk segera lulus.

Pelayanan yang prima dari institusi diperlukan juga kesadaran mahasiswa untuk menyelesaikan skripsi. Bila pelayanan baik tetapi mahasiswa tidak mau bekerja keras untuk menyelesaikan skripsi, ini sangat mengkhawatirkan bagi mahasiswa. Mereka selalu menunda mengerjakan skripsi, sehingga akan berdampak pada tertundanya mahasiswa lulus tepat waktu. Padahal, memulai untuk mengerjakan skripsi dibutuhkan kesadaran dan kesungguhan dalam mengerjakan skripsi. Selain itu, lingkungan mahasiswa dalam bergaul juga perlu diperhatikan. Mahasiswa seharusnya bergaul dengan teman yang bisa memberikan inspirasi untuk menyelesaikan skripsi. Pilihlah teman yang bisa diajak diskusi tentang penelitian yang sedang dilakukan. Cara ini bisa menjaga semangat mahasiswa untuk menyelesaikan studinya. Semangat ini juga dibutuhkan kemandirian mahasiswa dalam belajar. Membaca buku, e-book, jurnal penelitian, dan aktif bimbingan dengan dosen akan semakin memperlancar proses penyelesaian studi.

\section{SIMPULAN}

Dari data dan pembahasan berdasar analisis kesulitan mahasiswa D3 dan S1 dalam menyelesaikan studi tepat waktu dapat disimpulkan bahwa beberapa kendala bagi mahasiswa dalam menyelesaikan studinya adalah jarak yang jauh ke kampus untuk bimbingan, lingkungan tempat tinggal yang kurang kondusif, masih memiliki tanggungan kuliah teori/praktik, dan beberapa mahasiswa sibuk bekerja. Sedangkan menurut pendapat mahasiswa, beberapa dosen yang kurang aktif melaksanakan bimbingan.

Namun demikian, mahasiswa D3 Teknik Mesin maupun S1 Pendidikan Teknik Mesin masih berkomitmen untuk menyelesaikan studinya. Keseriusan mahasiswa tersebut ditunjukkan dengan berbagai usaha, seperti bimbingan secara intensif, belajar mandiri atau diskusi, dan mencari lingkungan yang kondusif untuk mengerjakan Proyek Akhir dan Skripsi.

Selain itu, mahasiswa berharap agar mata kuliah Proyek Akhir dan Skripsi bisa diambil lebih awal, penentuan dosen pengampu mata kuliah relevan dengan kompetensinya, jadwal pelaksanaan Proyek Akhir perlu ditambah frekwensinya, pihak jurusan perlu segera meremajakan peralatan bengkel, dan meninjau kembali administrasi Proyek Akhir dan Skripsi sehingga agar mempermudah mahasiswa menyelesaikan studinya.

Untuk mengatasi problematika yang dihadapi mahasiswa sebagaimana ditulis di depan, peneliti menyarankan agar dosen Pembimbing Akademik dan Pengurus Jurusan lebih aktif memantau keberadaan mahasiswamahasiswa yang sudah melewati masa studi ideal. Hal ini penting dilakukan, mengingat pada dasarnya para tersebut masih memiliki komitmen yang kuat untuk segera menyelesaikan studinya. 


\section{DAFTAR RUJUKAN}

Daulat Purnama Tampubolon, (2001). Perguruan Tinggi Bermutu. Jakarta: Gramedia.

Emerson, H. (1853-1931). Harington Emerson Papers. Diakses dari http. Wikipedia.org/wiki/harington_emerson pada 10 Agustus 2017.

J. Scheerens, (2000). Improving School Effectiveness. Paris: UNESCO.

Mochtar Buchori, (1994). Spektrum Problematika Pendidikan di Indonesia. Yogyakarta: Tiara Wacana.
Masri Singarimbun dan Sofian Effendi, (1989). Metode Penelitian Survei. Jakarta: LP3ES.

Smith, R.A., (1991). Innovative Teaching in Engineering. London: Ellis Horwood.

R.Saint-Paul, (1980). New Dimensions of Productivity and Development Strategies for the 1980s. Asian Producticity Congress (APC) 1980. Tokyo: Jepang.

Sigit Winarno, Sujana Ismaya, (2003). Kamus Besar Ekonomi. Bandung: Pustaka Grafika

Tjipto Utomo dan Kees Ruijter, (1989). Peningkatan dan Pengembangan Pendidikan. Jakarta: Gramedia. 